\title{
Cell Cycle Regulation in Retinal Progenitors by Glia-Derived Neurotrophic Factor and Docosahexaenoic Acid
}

\author{
M. Fernanda Insua, Andrés Garelli, Nora P. Rotstein, O. Lorena German, Andrés Arias, \\ and Luis E. Politi
}

\begin{abstract}
Purpose. A recent study has shown that glia-derived neurotrophic factor (GDNF) and docosahexaenoic acid (DHA) promote the survival and differentiation of retina photoreceptors. The current study was undertaken to investigate whether these molecules participate in cell cycle regulation in retinal progenitors in vitro.
\end{abstract}

Methods. Developmental changes in the expression of the stem cell marker nestin and of cell cycle and differentiated neuron markers were analyzed in neuroblasts obtained from 1-day-old rat retinas. The effects of GDNF and DHA on those changes were then determined.

Results. Expression of nestin, found in more than one third of neuroblasts at day 1 , rapidly decreased during development, with most neuroblasts acquiring the photoreceptor phenotype. GDNF increased the percentage of photoreceptor progenitors expressing nestin, whereas DHA reduced it, simultaneously enhancing photoreceptor differentiation. Several markers of cell cycle progression indicated that photoreceptor progenitors maintained an active cell cycle during the first 2 days in vitro. GDNF stimulated the cell cycle, increasing the number of dividing cells and generating more photoreceptor progenitors, whereas DHA induced cell cycle exit and photoreceptor differentiation. Analysis of the expression of the cyclin-Cdk inhibitor $\mathrm{p} 27^{\mathrm{Kip} 1}$ confirmed these results.

Conclusions. GDNF and DHA acted as molecular cues, counterbalancing the decision of photoreceptors to remain in or exit the cell cycle. The results strongly suggest that both factors participate in determining the number of photoreceptors in vitro, regulating the cell cycle and survival at early and late stages of development, respectively. Hence, GDNF and DHA may coordinately control the histogenesis of photoreceptors in the retina by modulating both neurogenesis and apoptosis. (Invest Ophthalmol Vis Sci. 2003;44:2235-2244) DOI:10.1167/iovs.02-0952

From the Institute of Biochemical Research (INIBIBB) and Universidad Nacional del Sur, Bahia Blanca, Buenos Aires, Argentina.

Supported by grants from the Universidad Nacional del Sur, National Research Council of Argentina (CONICET), and Fund for Research in Science and Technology (FONCYT). NPR and LEP are CONICET research career members, MFI and OLG have CONICET doctoral fellowships, and AG and AA have fellowships from the Universidad Nacional del Sur.

Submitted for publication September 17, 2002; revised November 28, 2002; accepted December 10, 2002.

Disclosure: M.F. Insua, None; A. Garelli, None; N.P. Rotstein, None; O.L. German, None; A. Arias, None; L.E. Politi, None

The publication costs of this article were defrayed in part by page charge payment. This article must therefore be marked "advertisement" in accordance with 18 U.S.C. $\$ 1734$ solely to indicate this fact.

Corresponding author: Luis E. Politi, INIBIBB, CC 857, B8000FWB Bahía Blanca, Buenos Aires, Argentina; inpoliti@criba.edu.ar.
$\mathrm{N}$ eural stem cell progenitors play a crucial role during neurogenesis of the nervous system and probably in adulthood, when those progenitors that remain represent a potential source of new neuronal cells that may restore the structure and function of damaged tissues. ${ }^{1-4}$ Uncovering the clues to the control of the proliferation and differentiation of neuronal progenitors is a prerequisite for making use of the potential of these cells for treating neurodegenerative diseases.

In the retina, stem cells rapidly proliferate at early stages of development, thus generating the required number of cells for proper retinal function. At later stages, multipotent progenitor cells downregulate their cell cycle activity and start their differentiation, which is coupled to irreversible cell cycle arrest. $^{5,6}$ The six major types of neuronal cells and the single glial cell type ${ }^{5,7}$ have been proposed to arise from progenitor cells that pass through several competence states, with their identity depending on the influence of extrinsic signals. ${ }^{8,9}$ Hence, a combination of intrinsic information and extrinsic cues contributes to establishing neuronal cell fate in the retina.

Considering that approximately $75 \%$ of cells in the rodent retina are photoreceptors and that cell death affects only $5 \%$ of them during development, ${ }^{5,10,11}$ regulation of the cell cycle in photoreceptor progenitors must be critical to controlling the final number of these neurons. The mechanisms involved in this regulation and in promoting cell cycle exit or reentry of multipotent progenitors in the retina are not completely understood. As in other regions of the central nervous system, neuroblast progression through the cell cycle depends on intrinsic and extrinsic signals, such as cyclin-dependent kinases (Cdk), their corresponding cyclins, and the expression of regulatory signals affecting cell fate. Cyclin D1 controls photoreceptor progenitor proliferation, ${ }^{12}$ whereas the Cdk-cyclin complex inhibitors $\mathrm{p} 27^{\mathrm{Kip} 1}$ and $\mathrm{p} 57^{\mathrm{Kip} 2}$ play an important role in controlling cell cycle exit in the retina. ${ }^{13,14}$ These two proteins belong to the so-called Cip/Kip family of Cdk inhibitors, sharing a broad spectrum of inhibitory effects on Cdkcyclin complexes. ${ }^{15,16}$ The absence or alteration of cell cycle controllers may have dramatic effects on the architecture of the mature retina, as has been shown in mice. ${ }^{13,16}$

Despite extensive research, information concerning the molecular signals that induce retinal progenitors to adopt a particular cell fate, end neurogenesis, and initiate their differentiation pathway is still not available. Trophic factors (TFs) are well known for their ability to regulate the ultimate number of cells in the retina by controlling apoptotic pathways leading to cell death, but little is known about their possible role as regulators of the cell cycle. Neurotrophin (NT)-3 has been proposed to control the cell cycle in dorsal root ganglion precursors, because in NT- $3^{-/-}$mice, sensory precursor cells undergo excessive mitosis followed by cell death. ${ }^{17}$ In the retina, the role of trophic factors in cell cycle regulation is still controversial. Basic fibroblast growth factor (bFGF) favors the self-renewal of retinal stem cells, ${ }^{18}$ whereas opposing roles in the regulation of the proliferation of retinal progenitors have been proposed for epidermal growth factor. ${ }^{18-20}$ Vascular en- 
dothelial growth factors-1 and -2 contribute to regulation of neurogenesis of photoreceptor and amacrine neurons, ${ }^{21}$ whereas transforming growth factor (TGF)- $\beta$ and bFGF regulate the number of photoreceptors in a retinal cell line. ${ }^{22}$

We have recently demonstrated that docosahexaenoic acid (DHA) and glia-derived neurotrophic factor (GDNF) are trophic factors for retina photoreceptors in vitro. ${ }^{23-26}$ DHA, the most abundant polyunsaturated fatty acid in retinal tissues, is particularly concentrated in photoreceptor outer segments, ${ }^{27}$ and supplementation of infant diets with this fatty acid improves visual development. ${ }^{28,29}$ GDNF, a distant member of the TGF- $\beta$ family, has potent neurotrophic effects on several neuronal types. ${ }^{30,31}$ Both molecules prevent apoptosis of photoreceptors and enhance their differentiation in vitro. ${ }^{23-26}$ We have shown ${ }^{23}$ that in addition to its survival-inducing properties, GDNF unexpectedly promotes proliferation of retina progenitor cells. This finding prompted us to explore further the regulatory effect of GDNF on neuroblast proliferation and to investigate whether DHA could also play a role in cell cycle control. This work showed that both molecules regulate the cell cycle, playing opposite roles in its control and counterbalancing its progression in retinal photoreceptor precursors during early stages of development. Therefore, our results point toward a novel role for TFs as regulators of the cell cycle in neuronal progenitors.

\section{Materials ANd Methods}

Albino Wistar rats bred in our own colony were used in all the experiments. One-day-old pups were used for in vitro experiments, whereas retinal sections were obtained from postnatal day (PN)0 and PN15 rats. All procedures involving animal use were performed in accordance with the ARVO Statement for the Use of Animals in Ophthalmic and Vision Research. Plastic 35-mm diameter culture dishes (Nunc) were purchased from InterMed (Naperville, IL); Dulbecco's modified Eagle's medium (DMEM) from Gibco-Life Technologies (Grand Island, NY); trypsin, trypsin inhibitor, transferrin, hydrocortisone, putrescine, insulin, polyornithine, selenium, gentamicin, 4,6diamidino-2-phenylindole (DAPI), fluorescein-conjugated secondary antibodies, propidium iodide, bromodeoxyuridine (BrdU), paraformaldehyde, bovine serum albumin, Triton X-100 and the monoclonal anti-syntaxin clone HPC-1 from Sigma (St. Louis, MO); secondary antibody, fluorescence-conjugated goat anti-mouse (Alexa 488) from Molecular Probes (Eugene, OR); tyramine from NEN Life Science Products (Boston, MA); and avidin-biotin complex (ABC) reagents from Vector Laboratories (Burlingame, CA). GDNF (Peprotech, Rocky Hill, NJ) was a generous gift from Nestor Carri (Institute of Molecular and Cellular Biology, La Plata, Argentina). Mouse monoclonal antibodies against the proliferating cell nuclear antigen (PCNA, p36 antigen), against p2 $7^{\text {Kip1 }}$ and rabbit polyclonal antibody $\mathrm{p} 57^{\mathrm{Kip} 2}$ were from Santa Cruz Biotechnology (Santa Cruz, CA). Rho4D2 was a generous gift from Robert Molday (University of British Columbia, Vancouver, British Columbia, Canada). Nestin monoclonal antibody was developed by Susan Hockfield (Yale University, New Haven, CT) and obtained from Developmental Studies Hybridoma Bank, under the auspices of the National Institute of Child Health and Development (NICHD, Bethesda, MD) and maintained by the University of Iowa, Department of Biological Science (Iowa City, IA). ${ }^{32,33}$ DHA (Sigma) was further purified by thinlayer chromatography and high-pressure liquid chromatography. ${ }^{23,24,34}$ Thymidine $\left[6-{ }^{3} \mathrm{H}\right]$ (specific activity, $17.9 \mathrm{Ci} / \mathrm{mmol}$ ) was purchased from NEN Life Science Products; autoradiographic emulsion (RPN-40) was Amersham Pharmacia Biotech, (Piscataway, NJ); developer (Dektol) from Eastman Kodak (Rochester, NY); and the fixer (Ultrarapid, Romek) from Exid SRL (Buenos Aires, Argentina). All other reagents used were of analytical grade.

\section{Retinal Cultures}

Pure retinal cultures were obtained according to procedures previously established..$^{35}$ In brief, 1-day-old rat retinas were dissected and dissociated by mechanical and trypsin digestion. The cells were then resuspended in a chemically defined medium, without the TFs required for photoreceptor cells, and seeded in 35-mm dishes. Cultures were incubated at $36^{\circ} \mathrm{C}$ in a humidified atmosphere of $5 \% \mathrm{CO}_{2}$ and fixed after different culture times with $2 \%$ paraformaldehyde in phosphate-buffered saline (PBS).

\section{GDNF and DHA Supplementation}

GDNF and DHA were added to the cultures immediately after the cells were seeded, at a final concentration of $4 \mathrm{ng} / \mathrm{mL}$ and $6.7 \mu \mathrm{M}$, respectively. GDNF was dissolved in DMEM, and the same volume of DMEM was added to control cultures. DHA was added in a complex with bovine serum albumin (BSA) in a 2:1-molar ratio in DMEM. ${ }^{24}$ The same volume and concentration of a BSA solution was added to control cultures. We have previously shown that DHA acts in a very narrow concentration range (i.e., 2-10 $\mu \mathrm{M}$ ), with higher concentrations leading to generalized neuronal death. ${ }^{24}$

\section{Immunocytochemical Analysis}

For immunocytochemical analysis of the cultures, the cells were sequentially fixed with paraformaldehyde, permeated with Triton X-100 for 15 minutes, incubated for 1 hour with primary antibodies and then with either biotinylated or fluorescence-conjugated secondary antibodies, as previously described. ${ }^{23}$ In some cases, tyramide amplification was used to improve detection. The number of amacrine and photoreceptor neurons, the two major cell types in the cultures, was determined by immunocytochemistry with the monoclonal antibodies HPC-1 and Rho4D2, respectively, and according to morphologic criteria previously reported. ${ }^{36-39}$

\section{Identification of Undifferentiated Cells and Multipotent Neuroblasts}

Undifferentiated cells usually bear numerous processes and have either a round or rather irregular morphology. In addition, pluripotent neuroblasts express the neuroectoderm marker nestin, a 200-kDa intermediate filament, whereas they fail to express the characteristic markers of mature retinal neurons. Therefore, the identity of pluripotent neuroblasts in vitro was assessed by several parameters: immunocytochemical determination of nestin, occurrence of mitotic figures, absence of markers of specific neuronal types, such as Rho4D2 and HPC-1, and an undifferentiated morphologic appearance in microscopy.

\section{Identification of Proliferating Neuroblasts}

Most photoreceptor progenitors complete their last mitotic division during the first postnatal days, ${ }^{40,41}$ the highest number of photoreceptors being generated at PNO. Several parameters were used to determine cell division of photoreceptor precursors in vitro. Mitotic figures were detected and quantified by fluorescence microscopy by sequentially permeating the cells with $0.1 \%$ Triton X-100 in PBS and labeling nuclei for 20 minutes with DAPI, a DNA marker. To further estimate cell division of photoreceptor precursors in vitro, $\left[{ }^{3} \mathrm{H}\right]$-thymidine or $\mathrm{BrdU}$ at a final concentration of $1 \mu \mathrm{Ci} / \mathrm{mL}$ and $50 \mu \mathrm{M}$, respectively, were added to the cultures after 7 hours of adding BSA (control), GDNF, DHA, or both. Unless specifically indicated, cultures were incubated for 24 hours at $36^{\circ} \mathrm{C}$ and then fixed with either paraformaldehyde or $2 \%$ glutaraldehyde in PBS. Cell labeling with [ $\left.{ }^{3} \mathrm{H}\right]$-thymidine was determined by autoradiographic methods in cultures fixed with glutaraldehyde, as previously described. ${ }^{42}$ BrdU-labeled cells were estimated by immunocytochemical analysis. The number of cells expressing PCNA p36 antigen, a $G_{1}-S$ cyclin used as a marker for proliferating cells, was detected by immunocytochemical methods, with a mouse 
monoclonal anti-PCNA antibody. The number of cells in each condition was then determined.

\section{Exit from the Cell Cycle}

To evaluate the percentage of progenitor cells committed to exit from the cell cycle, the amount of cells expressing the Cdk inhibitors $\mathrm{p} 27^{\mathrm{Kip} 1}$ and $\mathrm{p} 57^{\mathrm{Kip} 2}$ was assessed by immunocytochemistry. Double labeling of 1 - and 2-day cultures with DAPI and $\mathrm{p} 27^{\mathrm{Kip} 1}$ or $\mathrm{p} 57^{\mathrm{Kip} 2}$ was also performed, to determine whether the expression of these inhibitors occurs during mitosis and whether this expression is equally distributed in both daughter cells or asymmetrically in only one of the cells in the postmitotic pair. Whenever pairs of progenitor cells undergoing the mitotic telophase or completing cytokinesis were observed, the distribution of labeling in these pairs was also assessed.

\section{Statistical Analysis}

The results represent the average of results in three experiments ( \pm SD). Unless specifically indicated, each experiment was performed in triplicate. For cytochemical studies, the number of cells in each condition was determined by counting 10 fields (of $160-\mu \mathrm{m}$ diameter each) per sample, randomly selected, in each case. The average number of cells thus obtained was multiplied by a factor to calculate the total number of cells per 35-mm diameter dish. All dishes were counted blindly. Statistical significance was determined by Student's two-tailed $t$-test.

\section{Results}

\section{Early Development of Retinal Cells In Vitro}

At day 1 in vitro, two populations of cells, differing in the size of cell body, were present in the cultures. Small cells, with a cell body approximately 3 to $7 \mu \mathrm{m}$ in diameter, amounted to $44.7 \% \pm 2.9 \%$ of the total cells. The remaining had larger cell bodies that reached up to $20 \mu \mathrm{m}$ in diameter. At this time of development nearly half of the cells remained as undifferentiated progenitors, according to their morphologic appearance, and approximately $10 \%$ were completing their last mitotic divisions in vitro (Figs. 1A, 1B). Of interest, more than $95 \%$ of the dividing cells were small cells. These cells had either a round or rather irregular morphology, generally presenting a dark appearance and one or two processes that finally retracted, giving way to the short and usually unique axon characteristic of mature photoreceptor cells (Figs. 1C, 1D). At day 1 in vitro, very few small cells expressed the photoreceptor antigen Rho4-D2 (Figs. 1C, 1D). This expression increased gradually with development (Fig. 2B), ${ }^{23}$ until almost all small cells finally showed the characteristic features of photoreceptor cells. Large cells had a completely different fate, undergoing rapid differentiation. More than $50 \%$ of them adopted an amacrine cell morphology during the first 8 hours in vitro and by day $1,21.9 \% \pm 5.6 \%(n=3)$ expressed the amacrine cell marker HPC-1 (Figs. 1E, 1F). This percentage increased very rapidly until almost all large cells differentiated as amacrine neurons by days 4 to $5 .{ }^{39}$ Hence, whereas after 1 day in culture most large cells were already differentiated or on their way to differentiation as amacrine neurons, a significant proportion of small cells remained as photoreceptor progenitors (Figs. 1A, 1B), which either kept on cycling or entered the differentiation process.

\section{Developmental Regulation of Nestin Expression}

To further investigate whether undifferentiated retinal cells had the potential to continue in the cell cycle or turn into different cell types, the changes in the expression of nestin, Rho4D2, and HPC-1 during development in vitro were deter
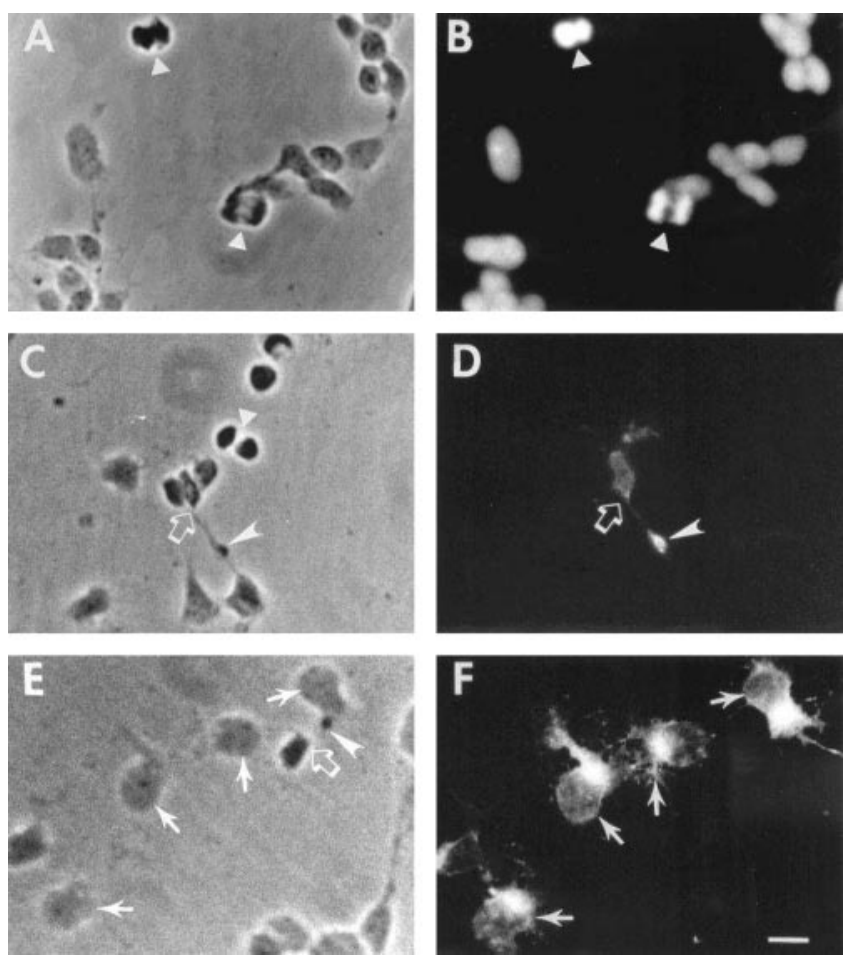

FIGURE 1. Mitosis and differentiation of retinal cells in vitro after 1 day of development. Phase $(\mathbf{A}, \mathbf{C}, \mathbf{E})$ and fluorescence $(\mathbf{B}, \mathbf{D}, \mathbf{F})$ photomicrographs of 1-day retinal cells stained with DAPI (B) or with monoclonal antibodies Rho4D2 (D) or HPC-1 (F), which selectively identify photoreceptor and amacrine neurons, respectively. Numerous undifferentiated cells underwent mitosis ( $\mathbf{A}, \mathbf{B}, \mathbf{C}$, small arrowheads). Large cells differentiated as amacrine neurons expressing their characteristic HPC-1 antigen (E, F, solid arrows), whereas small cells either underwent mitosis or started their differentiation as photoreceptors $(\mathbf{C}, \mathbf{E}$, open arrows), expressing opsin (D, open arrow) and showing the characteristic synaptic spherule (C-E, large arrowbeads). Bar: $10 \mu \mathrm{m}$.

mined. Consistent with their lack of differentiation, more than one third of the cells expressed nestin at day 1 (Figs. 2A, 3B). This expression appeared to be developmentally regulated, because nestin-positive cells rapidly decreased from $37 \%$ at day 1 to $16.5 \%$ at day 2 , and almost completely disappeared (approximately $0.1 \%$ ) by day 5 (Fig. $2 \mathrm{~A}$ ). Nestin localization also changed during development. Initially, it was usually localized in the immature processes, which frequently showed their endings more labeled than their origins, but just before starting differentiation, nestin lost its filamentous structure and tended to concentrate, with a punctate pattern, in the cell body (not shown). Expression of nestin strongly corresponded with an undifferentiated morphology. Generally, cells showing morphologic or immunochemical evidence of differentiation failed to express this protein (Fig. 3E, open arrow). Large undifferentiated cells had scarce nestin expression at day 1 , which was rapidly replaced by expression of HPC-1, suggesting that they had differentiated as amacrine neurons (not shown). Most nestin-positive cells were small cells. As a rule, the decrease in nestin expression in these cells was parallel to an increase in opsin expression (Fig. 2), from 3.2\% at day 1 to $6.5 \%$ by day 5 , which was consistent with the almost complete restriction of proliferation to small photoreceptor progenitor cells. By day 5 , when almost all cells had differentiated, nestin expression was negligible.

The pattern of nestin and opsin expression during neuronal development in vitro was similar to their in vivo counterpart. At PNO nestin was noticeably expressed in undifferentiated 


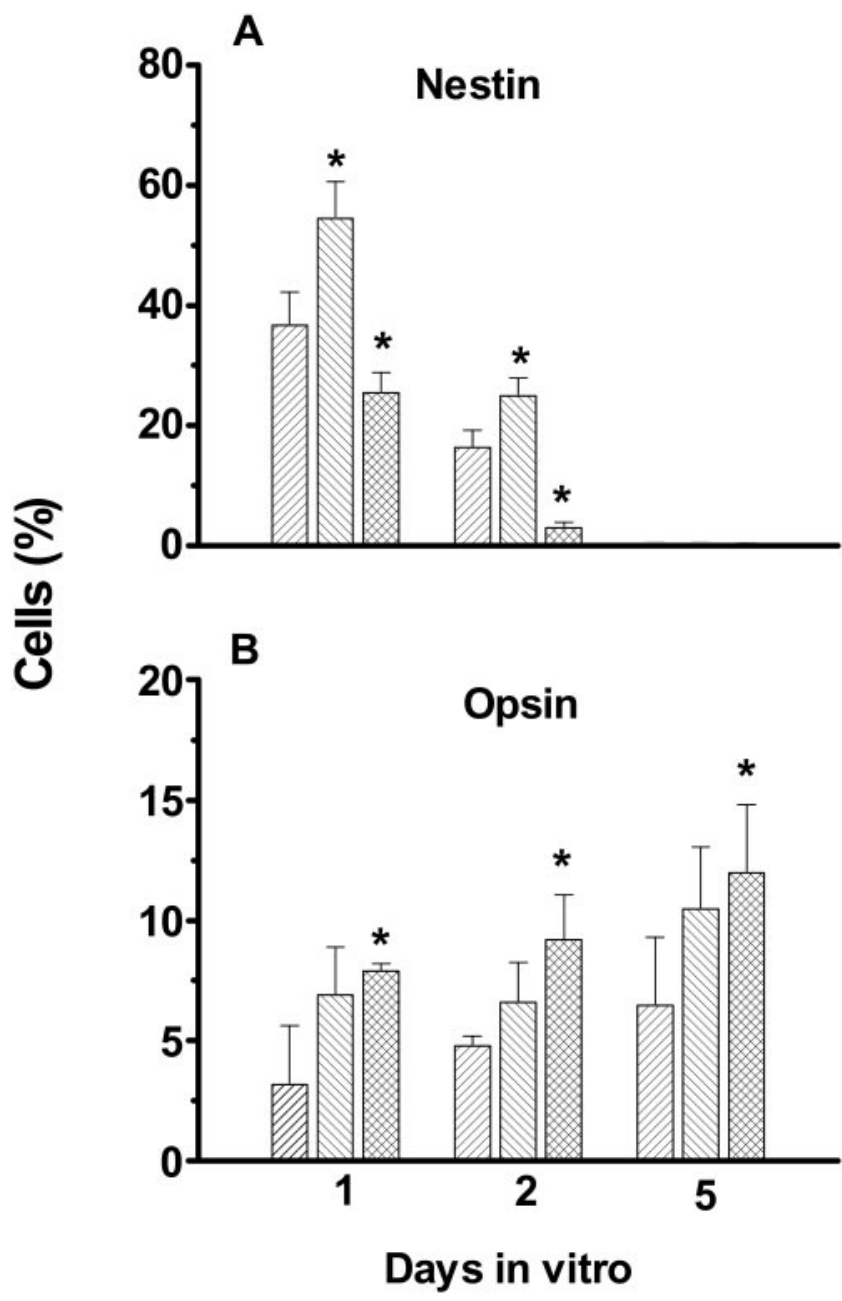

FigURE 2. Developmental regulation of nestin and opsin expression: effect of GDNF and DHA. The percentage of cells expressing the stem cell marker nestin, or rod marker opsin was determined at days 1, 2, and 5 in control $(\mathbb{Z})$, GDNF $(\mathbb{Q})$, or DHA (网)-supplemented cultures. All data are the mean \pm SD of results three separate experiments. *Significant difference from control conditions $(P \leq 0.05)$.

newborn rat retinas, showing a radial pattern of distribution in all layers (Figs. 4A, 4B). This expression gradually decreased during development, although more slowly than in vitro; by PN15 nestin was still detectable with a faint radial distribution (compare Fig. 2A with Figs. 4B, 4D). As observed in vitro, the decrease in expression of nestin was parallel to an increase in expression of opsin. Opsin was undetectable at day 0 , but was dramatically augmented by PN15 (Figs. 4E-H) and was almost completely confined to the outer segment layer (Fig. $4 \mathrm{H}$ ). Therefore, similar changes in protein expression accompanied development in vivo and in vitro, although culture conditions speeded up neuronal differentiation.

\section{Regulation of Nestin Expression by GDNF and DHA}

Addition of GDNF or DHA had opposite effects on the expression of nestin (Fig. 2A). GDNF favored proliferation, markedly increasing the percentage of undifferentiated, nestin-positive neuroblasts in comparison with those present in control cultures at days 1 and 2 (Fig. 2A). On the contrary, DHA promoted cell cycle exit, lowering nestin expression, and simultaneously and significantly increasing opsin expression, compared with controls (Fig. 2A). Of note, almost no nestin-positive cells were found in any culture condition by day 5 .

\section{Mitotic Divisions of Retinal Cells In Vitro}

Several parameters confirmed the existence of an active cell cycle in undifferentiated small cells. Mitotic figures, determined by DAPI staining, were found in 20,978 cells per dish (Fig. 5) and the number of cells expressing PCNA, a $G_{1}$ marker, was 31,780 cells per dish. In addition, BrdU labeling and $\left[{ }^{3} \mathrm{H}\right]$-thymidine incorporation showed that the number of cells in the $S$ phase of the cycle was 27,516 and 24,954 cells per dish, respectively (Fig. 5). On the contrary, a negligible proportion of large cells underwent cell division at this time of development (not shown).

\section{Effects of GDNF and DHA on Cell Cycle Progression of Retinal Neuroblasts}

To investigate whether GDNF and DHA regulates cell cycle progression in small cells, both trophic factors were separately added to the cultures immediately after the cells were seeded. The GDNF concentration used was $4 \mathrm{ng} / \mathrm{mL}$, because higher concentrations of this molecule were associated with nearly the same increase in the amount of mitotic figures (Fig. 5, inset). GDNF noticeably increased all parameters characteristic of cell cycle progression (Fig. 5). Thus, the number of neuroblasts undergoing mitosis almost doubled to 37,022 cells per dish (Fig. 5), and a similar increase was found in other markers of cell cycle progression, the number of cells labeled with either BrdU or $\left[{ }^{3} \mathrm{H}\right]$-thymidine or that expressed PCNA being
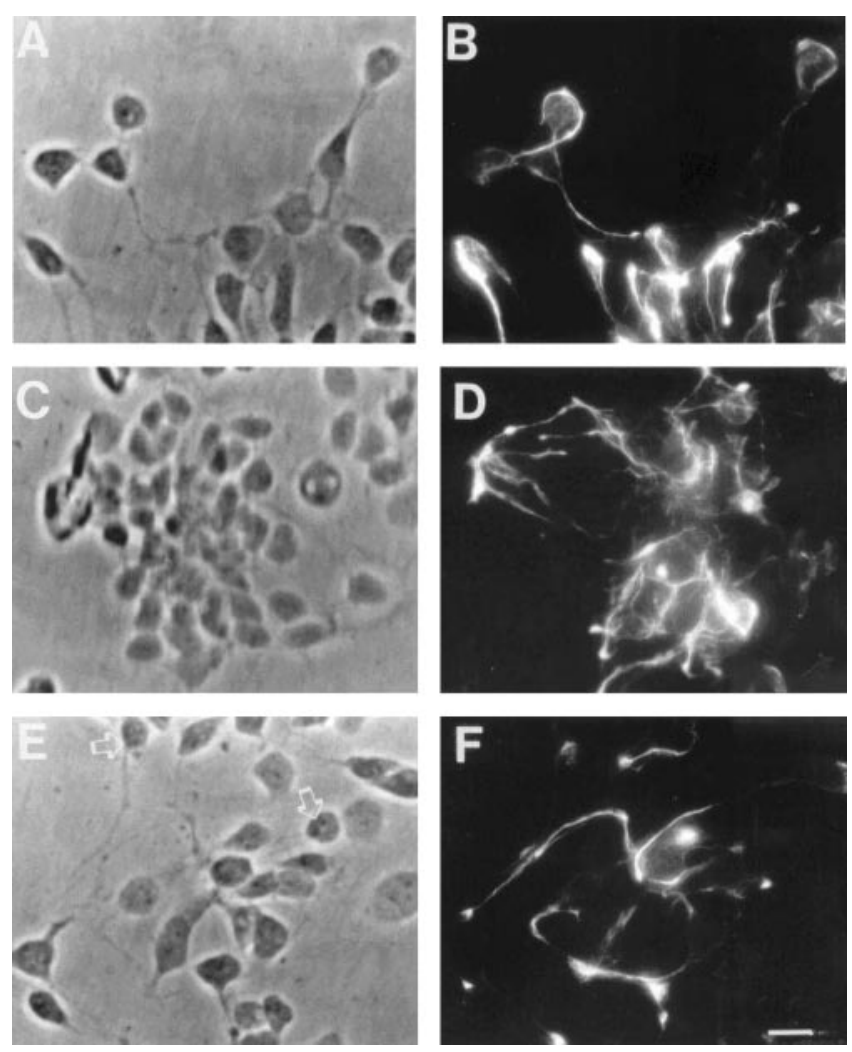

FIGURE 3. Developmental regulation of nestin expression: effects of GDNF and DHA. Phase (A, C, E) and fluorescence $(\mathbf{B}, \mathbf{D}, \mathbf{F})$ photomicrographs of 1-day cultures showing nestin expression in undifferentiated control (A, B), GDNF (C, D), or DHA (E, F)-supplemented cultures. Note that differentiated photoreceptors (E, arrows) lacked nestin expression. Bar: $10 \mu \mathrm{m}$. 


\section{PNO}
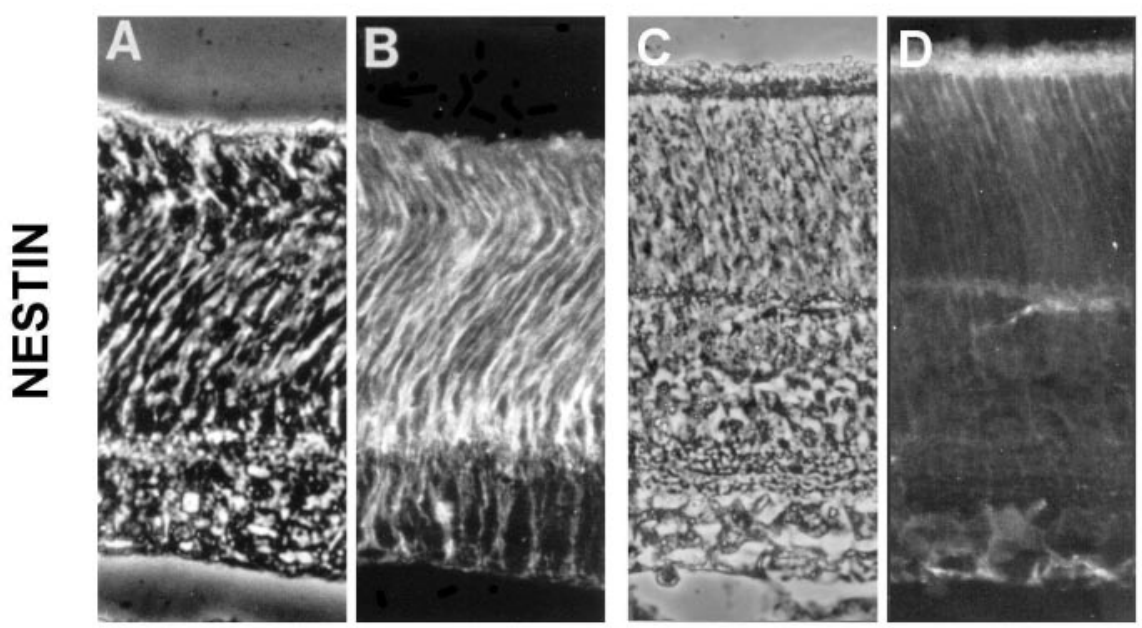

OS

ONL
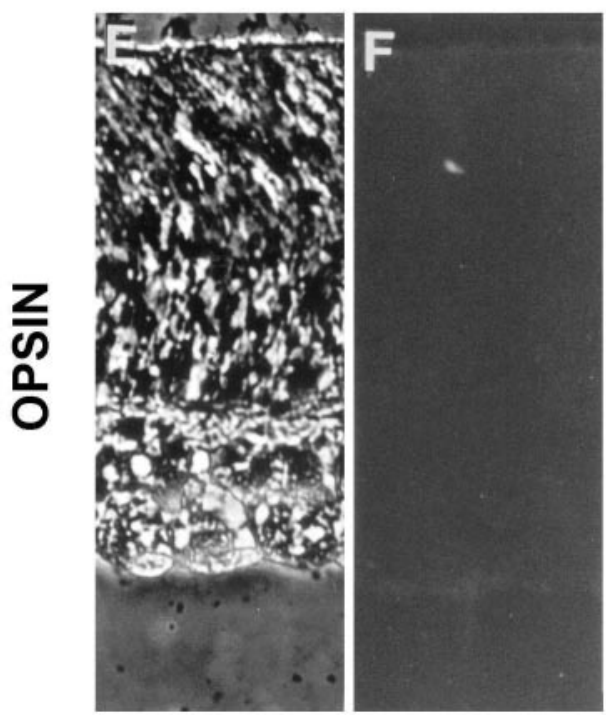
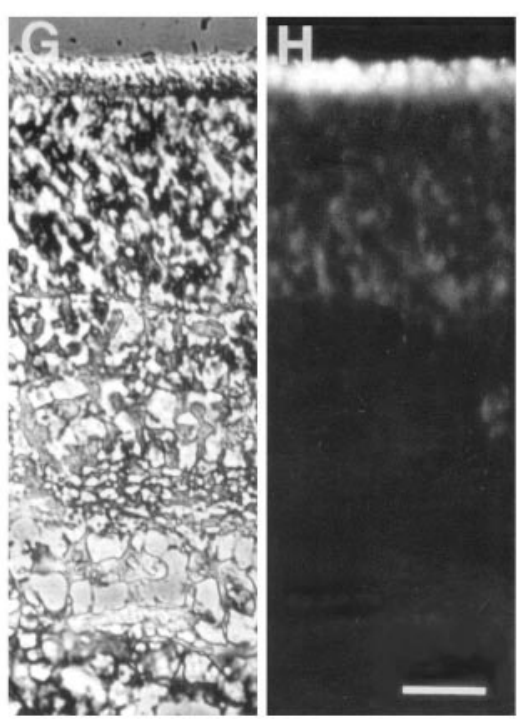

GCL

os

ONL

INL
$71,735,60,320$, and 52,405 cells per dish, respectively. DHA supplementation had the opposite effect, reducing by half to 10,800 cells per dish, the number of neuroblasts undergoing mitosis. Cells labeled with either $\left[{ }^{3} \mathrm{H}\right]$-thymidine or BrdU or expressing PCNA decreased similarly, to $13,068,14,660$, and 7,830 cells per dish, respectively (Fig. 5). When both GDNF and DHA were added to the cultures, the data were similar to those in control conditions (not shown). Therefore, GDNF and DHA had opposite effects-complementary regulation of cell cycle progression in photoreceptor progenitors.

\section{Evaluation of Retinal Progenitors Exiting the Cell Cycle}

Because $\mathrm{p} 57^{\mathrm{Kip} 2}$ and $\mathrm{p} 27^{\mathrm{Kip} 1}$ are essential for cells to exit the cell cycle, their expression was determined at different times of development. Expression of $\mathrm{p} 57^{\mathrm{Kip} 2}$ was always restricted to a fraction of the large amacrine progenitor cell subpopulation, with $10 \%$ and $8.8 \%$ of these cells expressing this protein at days 1 and 2 , respectively (Table 1 ). No $\mathrm{p} 57^{\mathrm{Kip} 2}$ expression was detected in photoreceptor progenitors. Expression of $\mathrm{p} 27^{\mathrm{Kip} 1}$ was more ubiquitous. At day 0 it was detected in approximately $70 \%$ and $61 \%$ of amacrine and photoreceptor progenitor cells, respectively, in control conditions (Table 1). This expression rapidly decreased in photoreceptor progenitors, being detected in approximately $25 \%$ and $21 \%$ of these cells by days 1 and 2, respectively, whereas it still remained high at day 2 in amacrine progenitors. At day 7, 26.8\% $\pm 2.1 \%(n=3)$ of photoreceptors and $37.3 \% \pm 4.1 \%(n=3)$ of amacrine neurons still expressed $\mathrm{p} 27^{\mathrm{Kip} 1}$. This suggests that $\mathrm{p} 27^{\mathrm{Kip} 1}$ expression was necessary to arrest the cell cycle and start differentiation in both neuronal precursors.

\section{Regulation of Cell Cycle Exit by DHA and GDNF}

To assess whether GDNF and DHA control the timing of cell cycle withdrawal in multipotent progenitor cells by regulating the levels of p57 Kip2 and p27 Kip1, their expression was analyzed in cultures separately treated with each trophic factor. The percentage of amacrine cell progenitors expressing $\mathrm{p} 57^{\mathrm{Kip} 2}$ or $\mathrm{p} 27^{\mathrm{Kip} 1}$ was unaffected by the addition of these factors and remained similar in GDNF- or DHA-supplemented cultures to that determined in the respective controls (Table 1). In photoreceptor progenitors, the percentage of cells expressing $\mathrm{p} 27^{\mathrm{Kip} 1}$ in GDNF-supplemented cultures was similar, approximately $25 \%$, to that in controls (Table 1 ). However, this expression was significantly higher, nearly 50\%, in DHA-supplemented cultures at day 1 . Hence, DHA upregulated p $27^{\text {Kip } 1}$ expression, thus prompting photoreceptor progenitors to exit the cell cycle and initiate their differentiation earlier than in control conditions. 


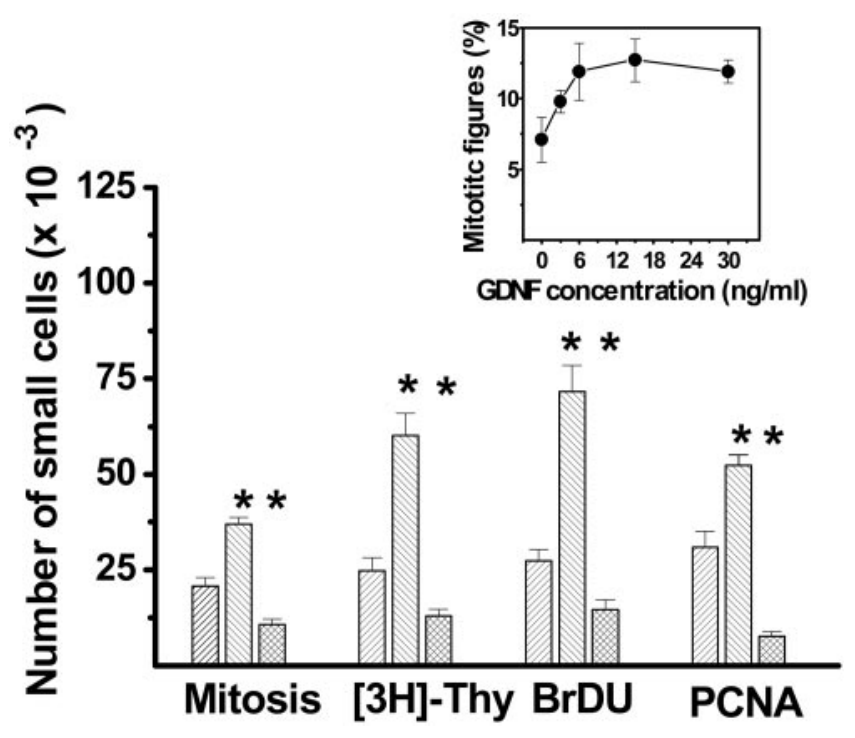

Figure 5. Effect of GDNF and DHA on the cell cycle of retinal progenitors. The number of photoreceptor progenitors (small cells) undergoing mitosis that incorporated BrdU or $\left[{ }^{3} \mathrm{H}\right]$-thymidine, or that expressed PCNA was determined at day 1 in vitro in control (ש), GDNF $(4 \mathrm{ng} / \mathrm{mL})(\mathbb{8})$, or DHA (四)-treated cultures. All data are the mean \pm $\mathrm{SD}$ of results in three separate experiments. Inset: dose-response curve, depicting the changes in the percentage of mitotic figures at different GDNF concentrations. *Significant differences from control conditions $(P \leq 0.05)$.

\section{Determination of Asymmetric Cell Divisions in Retinal Progenitor Cells}

During mitosis, the dividing daughter cells may distribute those proteins affecting cell cycle progression-that is, Cdk-cyclin complex inhibitors, in either a symmetrical or an asymmetrical manner. In the later case, the fate of each daughter cell would be quite different, one of them remaining and the other exiting the cell cycle. Hence, the percentage of daughter cell pairs that were completing or had just completed mitosis and expressed p $27^{\text {Kip } 1}$ either symmetrically or asymmetrically was assessed. A significant amount of the large (amacrine) progenitor cells symmetrically expressed HPC-1 (Fig. 6) and most of them expressed $\mathrm{p} 27^{\mathrm{Kip} 1}$ (Fig. 7B), confirming that they were in their way to becoming, or had already differentiated as amacrine cells. Asymmetric expression of $\mathrm{p} 27^{\mathrm{Kip} 1}$ was found in approximately $12 \%$ of these daughter cell pairs and symmetrically negative cells were almost negligible (Fig. 7B). In contrast, in the small (photoreceptor) daughter cell population at day 1, approximately $60 \%$ of these pairs symmetrically expressed p $27^{\mathrm{Kip} 1}$. However, $25 \%$ of the photoreceptor progenitor cell pairs did not express p2 $7^{\mathrm{Kip} 1}$ (Fig. $7 \mathrm{~A}$; negative symmetric cells) and over $15 \%$ showed an asymmetric expression of this inhibitor. Hence, although many small daughter cells were exiting the cell cycle, these results confirmed that a significant fraction of these cells was still in the cell cycle at day 1 .

\section{Effect of DHA and GDNF on Symmetric and Asymmetric Cell Divisions in Retinal Progenitor Cells}

The effects of DHA and GDNF on the symmetric or asymmetric distribution of $\mathrm{p} 27^{\mathrm{Kip} 1}$ expression in small and large daughter cell pairs was consistent with the just described effects of these trophic factors on cell cycle progression (Fig. 7). DHA and GDNF supplementation had no effect on $\mathrm{p} 27^{\mathrm{Kip} 1}$ distribution among pairs of large progenitor cells. For both neuronal progenitors in every condition studied, cell pairs symmetrically expressing p $27^{\text {Kip } 1}$ were the major fraction. However, in photoreceptor progenitors, this fraction was significantly reduced in GDNF-treated cultures, when compared with DHA-treated cultures, with a simultaneous increase in cell pairs symmetrically negative for $\mathrm{p} 27^{\mathrm{Kip} 1}$ expression (Fig. 7A). This suggests that a fraction of the cells still cycling in GDNF-supplemented cultures were induced to exit the cell cycle by addition of DHA.

\section{Expression of $\mathrm{p}^{2} 7^{\mathrm{Kip} 1}$ during Mitosis}

To investigate whether the cell fate of each daughter cell was predetermined before mitosis, mitotic cells were double labeled with DAPI and p $27^{\text {Kip } 1}$. As shown in Figure 8, at day 1, $72.6 \% \pm 9.1 \%(n=3)$ of the progenitor cells undergoing mitosis expressed $\mathrm{p} 27^{\mathrm{Kip} 1}$, strongly suggesting that this protein was synthesized during the interphase preceding mitosis.

\section{Discussion}

The present work shows that retinal progenitors from 1-dayold rats accomplished their last rounds of mitosis in vitro and, under the conditions described, either remained in the cell cycle, thus generating more progenitor cells, or exited it, differentiating as amacrine or photoreceptor neurons. These results also demonstrate that molecular cues from the environment such as GDNF and DHA, two photoreceptor survival molecules ${ }^{23-26,43-45}$ strongly influenced the decision of photoreceptor progenitors to remain in or depart the cell cycle,

TABLe 1. Expression of Cell Cycle Exit Markers p $57^{\mathrm{Kip} 2}$ and $\mathrm{p} 27^{\mathrm{Kip} 1}$ in Retinal Progenitor Cells during Early Development In Vitro

\begin{tabular}{|c|c|c|c|c|c|c|}
\hline \multirow[b]{2}{*}{ Condition } & \multicolumn{3}{|c|}{ Amacrine Cell Progenitors (\%) } & \multicolumn{3}{|c|}{ Photoreceptor Progenitors (\%) } \\
\hline & Day 0 & Day 1 & Day 2 & Day 0 & Day 1 & Day 2 \\
\hline \multicolumn{7}{|c|}{ Expression of $\mathrm{p} 57^{\mathrm{Kip} 2}$} \\
\hline Control & ND & $10.0 \pm 1.7$ & $8.8 \pm 1.1$ & ND & 0 & 0 \\
\hline GDNF & ND & $10.1 \pm 1.0$ & $7.3 \pm 1.4$ & ND & 0 & 0 \\
\hline DHA & ND & $11.2 \pm 1.2$ & $8.0 \pm 0.5$ & ND & 0 & 0 \\
\hline \multicolumn{7}{|c|}{ Expression of $\mathrm{p} 27^{\mathrm{Kip} 1}$} \\
\hline Control & $68.8 \pm 6.1$ & $62.4 \pm 6.4$ & $66.8 \pm 7.2$ & $60.6 \pm 2.9$ & $25.1 \pm 4.9$ & $21.9 \pm 6.5$ \\
\hline GDNF & $62.4 \pm 2.6$ & $68.1 \pm 7.1$ & $63.2 \pm 3.8$ & $61.1 \pm 4.4$ & $19.0 \pm 3.8$ & $16.7 \pm 9.6$ \\
\hline DHA & $62.4 \pm 3.1$ & $70.1 \pm 0.9$ & $72.0 \pm 6.6$ & $65.5 \pm 3.7$ & $49.3 \pm 10.2^{*}$ & $22.2 \pm 1.3$ \\
\hline
\end{tabular}

Retinal progenitor cells were grown in vitro without (control) or with either GDNF or DHA. After 6 hours (day 0) or 1 or 2 days in culture, the cells were fixed and processed by immunocytochemical methods to determine the expression of $\mathrm{p} 57^{\mathrm{Kip} 2}$ and p $27^{\mathrm{Kip} 1}$ in both types of neuronal progenitors

* Significant difference $(P<0.05)$ versus control and GDNF-supplemented cultures. 

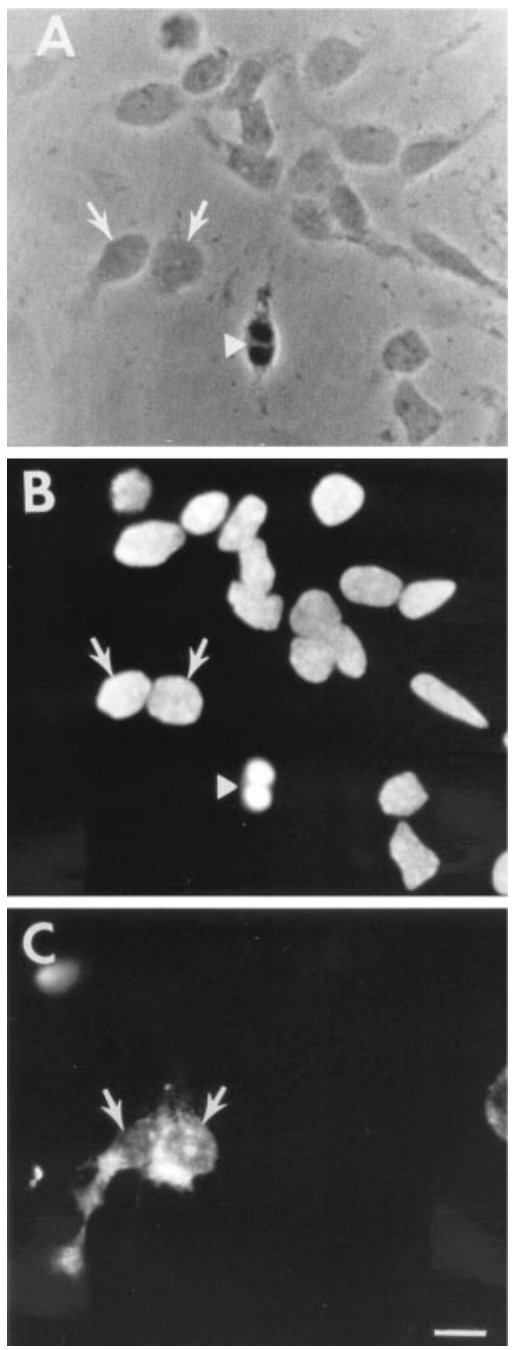

Figure 6. Symmetric divisions in progenitor cells. Phase (A) and fluorescence photomicrographs $(\mathbf{B}, \mathbf{C})$ of 1-day cultures labeled with DAPI (B) and HPC-1 (C) showing two pairs of small (arrowheads) and large (arrows) cells after completion of mitosis. Most large cells symmetrically expressed the amacrine cell marker HPC-1 (arrows). Bar: $10 \mu \mathrm{m}$.

thus having a central role in establishing the final number of mature photoreceptors.

At their first day in vitro, most cells were undifferentiated, and two populations of progenitor cells, large and small, with distinct morphologic, functional, and molecular properties, were observed. Large progenitor cells rapidly exited the cell cycle and differentiated as amacrine cells, whereas, a significant proportion of small cells presented a persistent nestin expression and remained in the cell cycle, gradually starting to express opsin and to exhibit the characteristic features of photoreceptor cells. Similarly, during retinal development, in vivo expression of nestin markedly decreased, with a concomitant increase in opsin expression, highly localized in the photoreceptor layer. Of note, some undifferentiated, nestin-expressing cells having a faint radial distribution, were still present in retinas of 15-day-old rats. These cells may be radial glial cells that may originate new neurons in both chick and mouse retina ${ }^{46,47}$ As a whole, these results suggest that most small, undifferentiated cells were photoreceptor precursors that remained in the cell cycle at day 1 in vitro. The timing of cell division in photoreceptor progenitors in vitro was coincident with that found in vivo, because most rods develop between PNO and PN2 in rodent retinas. ${ }^{5,11,48}$ The almost complete absence of mitosis of large undifferentiated cells was also consistent with results in vivo, because most amacrine neuron precursors have already completed their cell cycles at PN1 to PN3 in the mouse retina. ${ }^{10,11,48}$

Downregulation of cell cycle activity in progenitor cells was followed by a rapid decrease in nestin expression that preceded neuronal differentiation in both amacrine and photoreceptor neurons, in agreement with previous observations. ${ }^{12,14}$ Neuronal differentiation was closely related to cell cycle arrest. In the retina, $\mathrm{p} 27^{\mathrm{Kip} 1}$ involvement in the downregulation of the cell cycle previous to differentiation has been extensively demonstrated. Increased $\mathrm{p} 27^{\mathrm{Kip} 1}$ expression induces premature cell cycle exit ${ }^{13}$ and inhibits proliferation of retinal progenitor cells. Conversely, p2 $7^{\mathrm{Kip} 1}$-deficient mice show extended histogenesis of photoreceptors. ${ }^{14} \mathrm{p} 27^{\mathrm{Kip} 1}$ is persistently expressed in the adult retina and is also present in glial cells during development, where it may control some aspects of the mature phenotype, including reentry into the cell cycle. ${ }^{49}$ In our cultures, the triggering of $\mathrm{p} 27^{\mathrm{Kip} 1}$ expression was necessary for large and small progenitors to depart the cell cycle. The high proportion of progenitor cells expressing $\mathrm{p} 27^{\mathrm{Kip} 1}$ at day 0 roughly corresponded with the proportion

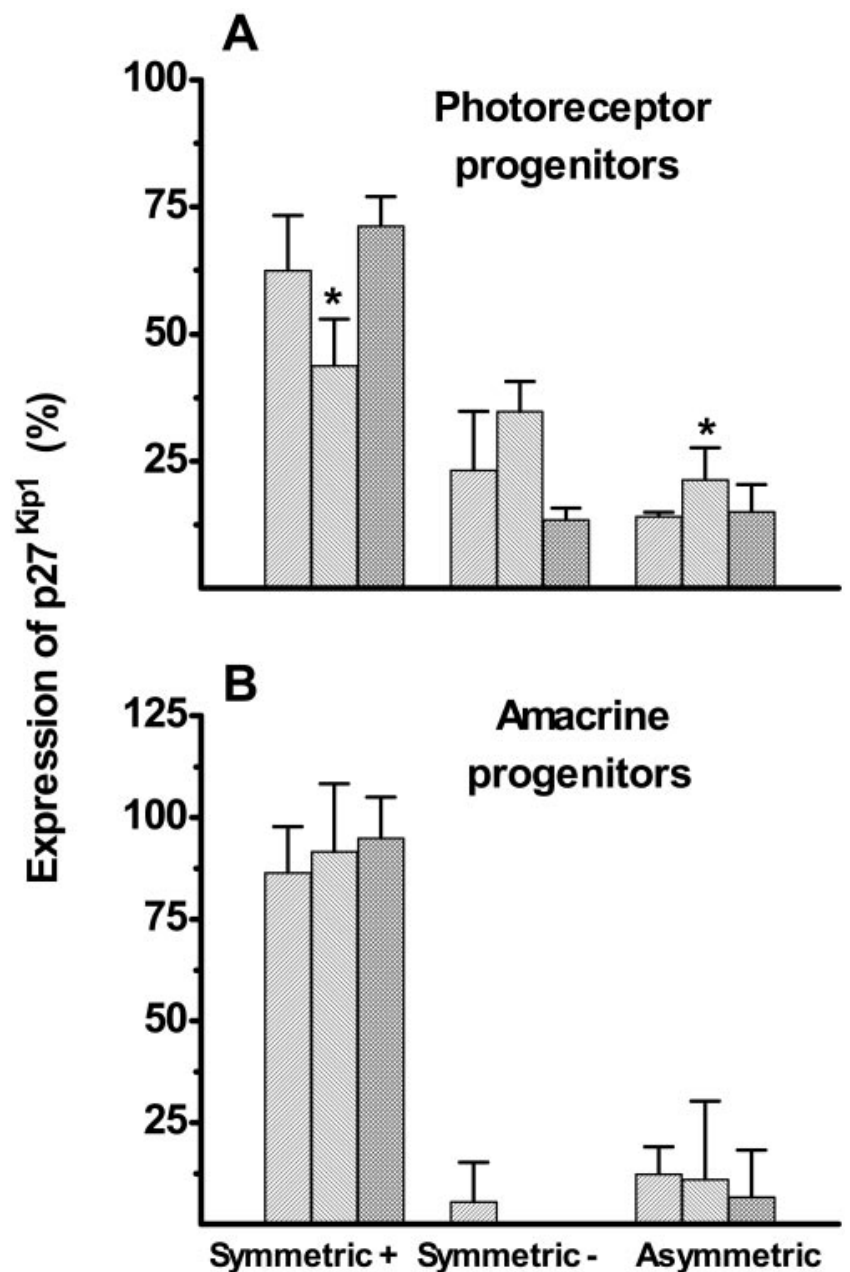

Figure 7. Symmetric and asymmetric expression of p27 Kip1 in large and small daughter cells after completion of mitosis. The percentage of small (A) and large (B) daughter cells asymmetrically (Asymmetric), symmetrically (Symmetric + ) expressing p2 $7^{\mathrm{Kip} 1}$, or not expressing it (Symmetric -) was determined at day 1 in control (进), GDNF $(\mathbb{D})$, or

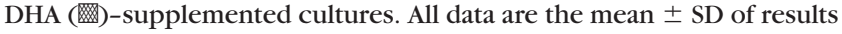
in three separate experiments. *Significant differences from control conditions $(P \leq 0.05)$. 

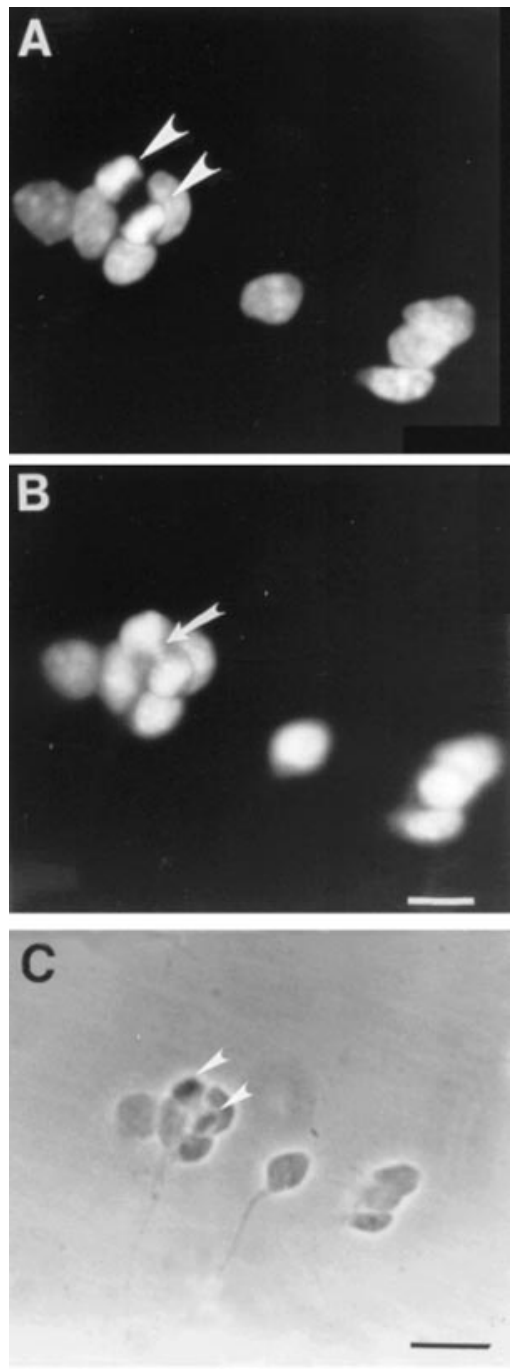

FiguRE 8. Expression of $\mathrm{p} 27^{\mathrm{Kip} 1}$ during mitosis in neuronal progenitor cells. Fluorescence $(\mathbf{A}, \mathbf{B})$ and phase $(\mathbf{C})$ photomicrographs of 1-day cultures labeled with DAPI (A) and showing p2 $7^{\mathrm{Kip} 1}$ expression (B). Arrowheads: the chromosomes moving toward the poles during anaphase. Note that $\mathrm{p} 27^{\mathrm{Kip} 1}$ (B, arrow) splits into the two daughter cells. Bar: (A, B) $10 \mu \mathrm{m}$; (C) $20 \mu \mathrm{m}$.

of cells exiting the cell cycle in the rat retina at this time in development. ${ }^{9,50}$ The extensive labeling of amacrine progenitors with $\mathrm{p} 27^{\mathrm{Kip} 1}$ clearly indicated that these cells had massively departed the cell cycle. However, the occurrence among photoreceptor progenitors of approximately $25 \%$ of daughter cell pairs symmetrically lacking p27 Kip1 expression supports the hypothesis that a significant proportion of photoreceptor progenitors remained cycling by days 1 and 2. Expression of p $27^{\text {Kip } 1}$ appeared to be developmentally regulated in amacrine and photoreceptor progenitors, decreasing with differentiation. However, both neuronal types retained a population of cells still labeled with $\mathrm{p} 27^{\mathrm{Kip} 1}$ at day 7 . Although it may be reasonable to speculate that a sustained p2 $7^{\mathrm{Kip} 1}$ expression would be necessary to prevent a catastrophic reentry into the cell cycle of differentiated cells, this hypothesis remains to be investigated.

An unexpected finding was that a significant amount of the progenitor cells undergoing mitosis were already expressing $\mathrm{p} 27^{\mathrm{Kip} 1}$. Because protein synthesis does not take place during the $\mathrm{M}$ phase of the cell cycle, our results raise an important biological problem, strongly suggesting that daughter cells may have synthesized $\mathrm{p} 27^{\mathrm{Kip} 1}$ in the preceding interphase. Therefore, daughter cells appear to have "inherited" the decision of leaving the cell cycle from their progenitor cell. If so, the symmetric-asymmetric distribution of $\mathrm{p} 27^{\mathrm{Kip} 1}$ during mitosis should have a major influence on the building of the cytoarchitecture of the retina during development. This is consistent with previous data ${ }^{51}$ showing that a marker for chick ganglion cells was first detected 15 minutes after these cells exited the $M$ phase, suggesting that its mRNA had been synthesized before mitosis. The current model proposes that the decision for a cell to progress into the $S$ phase is solely made in $G_{1}$. Our results support the hypothesis that, at least in the retina, the decision for a cell to exit the cell cycle may also be made in the previous cycle by its progenitor cell.?

In contrast to $\mathrm{p} 27^{\mathrm{Kip} 1}$, detected in photoreceptor and amacrine progenitors, $\mathrm{p} 57^{\mathrm{Kip} 2}$ was only found in a subpopulation of amacrine progenitors. Expression of $\mathrm{p} 57^{\mathrm{Kip} 2}$ is upregulated in late $G_{1},{ }^{52}$ thus mediating cell cycle exit in a restricted subset of retinal progenitors, apparently differentiating as amacrine cells. ${ }^{9,52}$ Hence, both $\mathrm{p} 57^{\mathrm{Kip} 2}$ and $\mathrm{p} 27^{\mathrm{Kip} 1}$ expression can induce large cell progenitors to exit the cell cycle and begin differentiation, although whether each signal is specific for a given amacrine subpopulation remains to be established.

Although death occurs in approximately 50\% of amacrine neurons during development, only $5 \%$ of the originally generated photoreceptors die, ${ }^{5}$ suggesting that the mechanisms regulating their genesis are crucial for achieving the required number of photoreceptors. These mechanisms probably involve cross talk between intrinsic and extrinsic clues, and our results suggest that GDNF and DHA may be at least two of these molecular cues. In vitro, these factors had opposite effects on cell cycle activity, which involved controlling the expression of key cell cycle regulators. GDNF is known to promote regeneration of sympathetic neurons in culture, ${ }^{53}$ but to our knowledge, a regulatory role for GDNF in the cell cycle has been observed only in undifferentiated spermatogonia. ${ }^{54}$ We have reported that GDNF increases the mitotic activity of proliferative neuroblasts. ${ }^{23}$ Our present results show that GDNF stimulated cell cycle progression and increased the number of photoreceptor progenitors. To accomplish this, GDNF may activate one or multiple signaling pathways. It has been shown recently ${ }^{55}$ that in chromaffin cells, GDNF-activated mitogenic activity is blocked by phosphatidylinositol-3 kinase (PI-3 K) inhibitors. GDNF may act similarly in our system, activating the PI-3 K pathway in photoreceptor progenitors. Whatever the signaling pathway involved, cell cycle activation usually involves upregulation of cyclin D1, leading to activation of its corresponding $\mathrm{Cdk}$, thus promoting the transition from $G 1$ to the $S$ phase of the cell cycle. In the present work, both $G_{1}$ and $S$ phase markers were significantly enhanced after GDNF addition. The time lapse for promoting cell division in photoreceptors seems to be limited, because undifferentiated cells almost disappear after 3 to 4 days in culture, whatever the culture condition. By enhancing the division of photoreceptor progenitors at the time of development at which photoreceptors are being generated, GDNF may be crucial in defining, at least in vitro, the initial size of the photoreceptor pool. Once these cells start their differentiation, GDNF acts as a trophic factor, preventing apoptosis and augmenting expression of opsin. ${ }^{23}$

In contrast, DHA induced photoreceptor progenitors to decrease cell cycle activity, increase the expression of cell cycle inhibitors, and thereafter exit the cell cycle. As the percentage of photoreceptor progenitors decreased, the proportion of small cells acquiring morphologic and molecular features characteristic of rod photoreceptors progressively increased, suggesting DHA was necessary for photoreceptor progenitors to start differentiation. Recent reports suggest a role 
for DHA in cell cycle regulation, reducing mitosis in several tumor cell lines by preventing $S$ phase entry, ${ }^{56}$ an effect that has been ascribed to hypophosphorylation of $\mathrm{Rb}$ and to a drastic increase in the level of $\mathrm{p} 27^{\mathrm{Kip} 1}$ in melanoma cells. ${ }^{57}$ To our knowledge, this is the first report showing that DHA plays a regulatory function on the cell cycle of retinal photoreceptor progenitors. This suggests that DHA may induce withdrawal from the cell cycle in different cell types by regulating similar molecular pathways.

The novel function of this fatty acid in the cell cycle of photoreceptor progenitors reported herein suggests that it may, in coordination with GDNF, ${ }^{23}$ actively participate in regulating the number of photoreceptor cells in the retina. The finding of a nuclear receptor for $\mathrm{DHA}^{58}$ gives additional support to its role as a trophic factor. DHA could have a multiplicity of effects on rod photoreceptors at different times of their development. It may initially be at least one of the extrinsic cues necessary for photoreceptor progenitors to stop dividing and start differentiation. This may involve the enhancement by DHA of the transcription of genes involved in cell cycle downregulation, such as $\mathrm{p} 27^{\mathrm{Kip} 1}$, and of at least some of the genes required for photoreceptor differentiation, such as opsin. Later, DHA may operate as a trophic factor, promoting photoreceptor survival and concurrently further enhancing differentiation. In vivo, DHA levels increase from roughly 5\% to nearly $30 \%$ during the first month of life in the developing retina. ${ }^{34}$ In agreement with its proposed role in cell cycle exiting, our results show that when added together with GDNF, DHA can inhibit GDNF-induced upregulation of the cell cycle. It seems reasonable to speculate that high levels of DHA at the beginning of retina postnatal development, when most photoreceptors are being generated, ${ }^{5}$ would be a clear disadvantage, because such concentrations would force photoreceptor progenitors to leave the cell cycle prematurely. However, once photoreceptors become dependent on their specific trophic factors for survival, a high concentration of DHA would be crucial to avoid apoptosis.

Because so few of the originally generated photoreceptors die, the tight control of the mechanisms of photoreceptor genesis and survival is essential for proper retinal function and may give a clue to the combined regulatory effects of GDNF and DHA in these mechanisms. Altogether, our results open the interesting possibility that GDNF and DHA may control photoreceptor neurogenesis in the retina by regulating the cell cycle at early stages of development, thus adjusting the number of photoreceptors initially formed and, later on, modulating their final number by controlling apoptosis. These novel functions of trophic factors in controlling and coordinately regulating the cell cycle in retinal cells should alert us to similar functions of these or other trophic molecules in the retina in vivo as well as in other regions of the nervous system. Our knowledge of the environmental factors and mechanisms that control cell cycle progression or arrest is of paramount importance in the design of new cell replacement strategies for the treatment of eye diseases characterized by progressive and irreversible photoreceptor losses.

\section{Acknowledgments}

The authors thanks Beatriz de los Santos for excellent technical assistance.

\section{References}

1. Jin K, Minami M, Lan JQ, et al. Neurogenesis in dentate subgranular zone and rostral subventricular zone after local cerebral ischemia in the rat. Proc Natl Acad Sci USA. 2001;98:4710-4715.

2. Eriksson PS, Perfilieva E, Bjork-Eriksson T, et al. Neurogenesis in the adult human hippocampus. Nat Med. 1998;4:1313-1317.
3. McKay R. Stem cells in the central nervous system. Science. 1997; 276:66-71.

4. Van der Kooy D, Weiss S. Why stem cells? Science. 2000;287: 1439-1441.

5. Cepko CL, Austin CP, Yang X, Alexiades M, Ezzeddine D. Cell fate determination in the vertebrate retina. Proc Natl Acad Sci USA. 1996;93:589-595.

6. Reh TA, Levine EM. Multipotential stem cells and progenitors in the vertebrate retina. J Neurobiol. 1998;36:206-220.

7. Turner DL, Snyder EY, Cepko CL. Lineage-independent determination of cell type in the embryonic mouse retina. Neuron. 1990;4: 833-845.

8. Cepko CL. The roles of intrinsic and extrinsic cues and bHLH genes in the determination of retinal cell fates. Curr Opin Neurobiol. 1999;9:37-46.

9. Livesey FJ, Cepko CL. Vertebrate neural cell-fate determination: lessons from the retina. Nat Rev Neurosci. 2001;2:109-118.

10. Young RW. Cell differentiation in the retina of the mouse. Anat Rec. 1985;212:199-205.

11. Young RW. Cell proliferation during postnatal development of the retina in the mouse. Brain Res. 1985;353:229-239.

12. Skapek SX, Lin SC, Jablonski MM, et al. Persistent expression of cyclin D1 disrupts normal photoreceptor differentiation and retina development. Oncogen. 2001;20:6742-6751.

13. Dyer MA, Cepko CL. p $27^{\mathrm{Kip} 1}$ and $\mathrm{p} 57^{\mathrm{Kip} 2}$ regulate proliferation in distinct retinal progenitor cell populations. J Neurosci. 2001;21: 4259-4271.

14. Levine EM, Close J, Fero M, Ostrovsky A, Reh TA. p $27^{\text {Kip } 1}$ regulates cell cycle withdrawal of late multipotent progenitor cells in the mammalian retina. Dev Biol. 2000;219:299-314.

15. Sherr CJ, Roberts JM. CDK inhibitors: positive and negative regulators of G1-phase progression. Genes Dev. 1999;13:1501-1512.

16. Nakayama K, Nakayama K. Cip/Kip cyclin-dependent kinase inhibitors: brakes of the cell cycle engine during development. Bioessays. 1998;20:1020-1029.

17. EIShamy WM, Fridvall LK, Ernfors P. Growth arrest failure, G1 restriction point override, and $S$ phase death of sensory precursor cells in the absence of neurotrophin-3. Neuron. 1998;21:10031015.

18. Tropepe V, Coles BL, Chiasson BJ, et al. Retinal stem cells in the adult mammalian eye. Science. 2000;287:2032-2036.

19. Ahmad I, Dooley CM, Afiat S. Involvement of Mash1 in EGFmediated regulation of differentiation in the vertebrate retina. Dev Biol. 1998;194:86-98.

20. Ahmad I, Dooley CM, Thoreson WB, Rogers JA, Afiat S. In vitro analysis of mammalian retinal progenitor that gives rise to neurons and glia. Brain Res. 1999;831:1-10.

21. Yourey PA, Gohari S, Su JL, Alderson RF. Vascular endothelial cell growth factors promote the in vitro development of rat photoreceptor cells. J Neurosci. 2000;20:6781-6788.

22. Ezeonu I, Derrickson B, Dutt K. Cell fate decisions in a human retinal precursor cell line: basic fibroblast growth factor- and transforming growth factor-alpha-mediated differentiation. DNA Cell Biol. 2000;19:527-537.

23. Politi LE, Rotstein NP, Carri NG. Effects of GDNF on neuroblast proliferation and photoreceptor survival: additive protection with docosahexaenoic acid. Invest Ophthalmol Vis Sci. 2001;42:30083015.

24. Rotstein NP, Aveldaño MI, Barrantes FJ, Politi LE. Docosahexaenoic acid is required for the survival of rat retinal photoreceptors in vitro. J Neurochem. 1996;66:1851-1859.

25. Rotstein NP, Aveldaño MI, Barrantes FJ, Roccamo AM, Politi LE. Apoptosis of retinal photoreceptors during development in vitro: protective effect of docosahexaenoic acid. J Neurochem. 1997;69: 504-513.

26. Rotstein NP, Politi LE, Aveldaño MI. Docosahexaenoic acid promotes differentiation of developing photoreceptors in culture. Invest Ophthalmol Vis Sci. 1998;39:2750-2758.

27. Fliesler SJ, Anderson RE. Chemistry and metabolism of lipids in the vertebrate retina. Prog Lipid Res. 1983;22:79-131. 
28. Birch EE, Birch DG, Hoffman DR, Uauy R. Dietary essential fatty acid supply and visual acuity development. Invest Ophthalmol Vis Sci. 1992;33:3242-3253.

29. Carlson SE, Werkman SH, Peeples JM, Wilson WM. Long chain fatty acids and early visual and cognitive development of preterm infants. Eur J Clin Nutr. 1994;48:S27-S30.

30. Matheson CR, Carnahan J, Urich JL, Bocangel D, Zhang TJ, Yan Q Glial cell line-derived neurotrophic factor (GDNF) is a neurotrophic factor for sensory neurons: comparison with the effects of the neurotrophins. J Neurobiol. 1997;32:22-32.

31. Nosrat CA, Tomac A, Lindqvist E, et al. Cellular expression of GDNF mRNA suggests multiple functions inside and outside the nervous system. Cell Tissue Res. 1996;286:191-207.

32. Hockfield S, McKay RD. Identification of major cell classes in the developing mammalian nervous system. J Neurosci. 1985;5:3310 3328.

33. Lendahl U, Zimmerman LB, McKay RD. CNS stem cells express a new class of intermediate filament protein. Cell. 1990;60:585-595.

34. Politi L, Rotstein N, Carri N. Effects of docosahexaenoic acid on retinal development: cellular and molecular aspects. Lipids. 2001; 36:927-935.

35. Politi LE, Bouzat C, de los Santos EB, Barrantes FJ. Heterologous retinal cultured neurons and cell adhesion molecules induce clustering of acetylcholine receptors and polynucleation in mouse muscle BC3H-1 clonal cell line. J Neurosci Res. 1996;43:639-651.

36. Barnstable CJ. Monoclonal antibodies which recognize different cell types in the rat retina. Nature. 1980;286:231-235.

37. Kljavin IJ, Lagenaur C, Bixby JL, Reh TA. Cell adhesion molecules regulating neurite growth from amacrine and rod photoreceptor cells. J Neurosci. 1994;14:5035-5049.

38. Hicks D, Barnstable CJ. Different rhodopsin monoclonal antibodies reveal different binding patterns on developing and adult rat retina. J Hystochem Cytochem. 1987;35:1317-1328.

39. Politi LE, Rotstein NP, Salvador G, Giusto NM, Insua MF. Insulinlike growth factor-I is a potential trophic factor for amacrine cells J Neurochem. 2001;76:1199-1211.

40. Carter-Dawson LD, LaVail MM. Rods and cones in the mouse retina. II. Autoradiographic analysis of cell generation using tritiated thymidine. J Comp Neurol. 1979;188:263-272.

41. Morrow EM, Furukawa T, Cepko CL. Vertebrate photoreceptor cell development and disease. Trends Cell Biol. 1998;8:353-358.

42. Politi LE, Lehar M, Adler R. Development of neonatal mouse retinal neurons and photoreceptors in low density cell culture. Invest Opbthalmol Vis Sci. 1988;29:534-543.

43. Ogilvie JM, Speck JD, Lett JM. Growth factors in combination, but not individually, rescue rd mouse photoreceptors in organ culture. Exp Neurol. 2000;161:676-685.
44. Frasson M, Picaud S, Leveillard T, et al. Glial cell line-derived neurotrophic factor induces histologic and functional protection of rod photoreceptors in the $\mathrm{rd} / \mathrm{rd}$ mouse. Invest Ophthalmol Vis Sci. 1999; 40:2724-2734.

45. Carwile ME, Culbert RB, Sturdivant RL, Kraft TW. Rod outer segment maintenance is enhanced in the presence of bFGF, CNTF and GDNF. Exp Eye Res. 1998;66:791-805.

46. Fischer AJ, Reh TA. Müller glia are a potential source of neural regeneration in the postnatal chicken retina. Nat Neurosci. 2001; 4:247-252.

47. Heins N, Malatesta P, Cecconi F, et al. Glial cells generate neurons: the role of the transcription factor PAX-6. Nat Neurosci. 2002;5: 308-315.

48. Marquardt T, Gruss P. Generating neuronal diversity in the retina: one for nearly all. Trends Neurosci. 2002;25:32-38.

49. Vetter ML, Moore K. Becoming glial in the neural retina. Dev Dyn. 2001;221:146-153.

50. Alexiades MR, Cepko CL. Quantitative analysis of proliferation and cell cycle length during development of the rat retina. Dev Dyn. 1996;205:293-307.

51. Waid DK, McLoon SC. Immediate differentiation of ganglion cells following mitosis in the developing retina. Neuron. 1995;14:117124.

52. Dyer MA, Cepko CL. The $\mathrm{p} 57^{\mathrm{Kip} 2}$ cyclin kinase inhibitor is expressed by a restricted set of amacrine cells in the rodent retina. J Comp Neurol. 2001;429:601-614.

53. Andres R, Forgie A, Wyatt S, Chen Q, de Sauvage FJ, Davies AM. Multiple effects of artemin on sympathetic neuron generation, survival and growth. Development. 2001;128:3685-3695.

54. Meng X, Lindahl M, Hyvonen ME, et al. Regulation of cell fate decision of undifferentiated spermatogonia by GDNF. Science. 2000;287:1489-1493.

55. Powers JF, Schelling KH, Tischler AS. Chromaffin cell mitogenesis by neurturin and glial cell line-derived neurotrophic factor. Neuroscience. 2001;108:341-349.

56. Chen ZY, Istfan NW. Docosahexaenoic acid, a major constituent of fish oil diets, prevents activation of cyclin-dependent kinases and S-phase entry by serum stimulation in HT-29 cells. Prostaglandins Leukot Essent Fatty Acids. 2001;64:67-73.

57. Albino AP, Juan G, Traganos F, et al. Cell cycle arrest and apoptosis of melanoma cells by docosahexaenoic acid: association with decreased pRb phosphorylation. Cancer Res. 2000;60:4139-4145.

58. Mata de Urquiza AM, Liu S, Sjoberg M, et al. Docosahexaenoic acid, a ligand for the retinoid $\mathrm{X}$ receptor in mouse brain. Science. 2000;290:2140-2144. 